\title{
DIREITOS FUNDAMENTAIS E CRISE: VIOLÊNCIA, IMPUNIDADE, CORRUPÇÃO INSTITUCIONALIZADA E O PRINCÍPIO DA NÃO CULPABILIDADE NO HC N. ${ }^{\circ}$ 126.292/SP DO STF
}

\author{
FUNDAMENTAL RIGHTS AND CRISIS: VIOLENCE, IMPUNITY, \\ INSTITUTIONALIZED CORRUPTION AND THE PRINCIPLE OF NON-CULPABILITY \\ IN HC N. ${ }^{\circ} 126.292 / S P$ FROM STF
}

\begin{abstract}
Alessandra Garcia Marques
Mestranda em Direito Constitucional pelo IDP. Graduada em História pela Universidade Federal de Uberlândia. Graduada em Direito pela Universidade Federal de Uberlândia. Pós-graduada em Direito Sanitário pela UNB, em Direito Tributário pela UCAM e em Direito Penal e Processual Penal pela UCAM. Atualmente é Promotora de Justiça titular da Promotoria de Justiça de Defesa do Consumidor do Ministério Público do Estado do Acre. Ministra cursos de Direito do Consumidor na Escola da Magistratura do Acre ESMAC. Ministra curso na Escola Nacional de Defesa do Consumidor do Ministério da Justiça - ENDC. E-mail: amarques@mpac.mp.br
\end{abstract}

Recebido em: 10/05/2016

Aprovado em: 26/09/2016

Doi: $10.5585 /$ rdb.v16i7.386

RESUMO: O presente artigo busca compreender em que medida pode se dar a relação entre as crises e os direitos e garantias fundamentais, que constituem o pilar do estado democrático de direito brasileiro, especificamente a partir da análise do recente julgamento pelo Supremo Tribunal Federal do HC n. ${ }^{\circ}$ 126.292/SP. Publicado o Acórdão, este trabalho será realizado por meio da apreciação crítica dos fundamentos contidos no voto do Relator, que foi vencedor, quando será feita uma análise conceitual do princípio da não culpabilidade, abordando, também, as disciplinas da prisão e da antecipação da tutela penal em nível infraconstitucional no sistema jurídico brasileiro. Ao final, é possível verificar que a mudança indicada na jurisprudência do STF acerca do princípio da presunção de inocência guarda relação com a grave crise política, econômica e ética pela qual o Brasil passa, e que a redefinição do alcance desse princípio evidenciada no julgamento do STF demonstra que em momentos de crises direitos e garantias fundamentais podem estar sujeitos a riscos de ser tangenciados por meio da atividade legislativa do estado ou da jurisprudência.

Palavras-chave: Princípio da Presunção de Inocência. Direitos e Garantias Fundamentais. Crise. Antecipação da Tutela Penal.

ABSTRACT: This article wants to understand to what extent the relation between the crises and the fundamental rights and guarantees that constitute the centre of the brazilian democratic state of law, specifically starting from the analysis of the recent judgement for Supreme Court of HC $\mathrm{n}^{\circ}{ }^{\mathrm{o}}$ 126.292/SP. With the publication of the decision, this work will be accomplished through the critical appreciation of the foundations contained in the Minister Reporter's vote, that was winner, when it will be made a conceptual analysis of the principle of the presumption of innocence, approaching the disciplines of the prison and of the anticipation of the criminal judicial protection 
in infraconstitucional level in the Brazilian juridical system. At the end it is possible to verify that the suitable change in the jurisprudence of STF regarding the presumption of innocence is related with the serious political, economical and ethics brazilian crisis, and that the controversial redefinition of the reach of the principle of the presumption of innocence evidenced in the judgement of STF demonstrates that in certain moments of crises the fundamental rights and guarantees may be at risk of being touched by means the legislative activity of the state or of the jurisprudence.

Keywords: Principle of the Presumption of Innocence. Fundamental Rights and Guarantees. Crisis. Anticipation of the Criminal Judicial Protection.

SUMÁRIO: Introdução. 1 O ordenamento jurídico brasileiro e as crises. 2 O HC n. ${ }^{\text {o }}$ 126.292/SP do STF. 3 A crise brasileira: o contexto histórico em que se insere o $\mathrm{HC} \mathrm{n.}{ }^{\circ}$ 126.292/SP. $4 \mathrm{O}$ princípio da presunção de não culpabilidade, a disciplina das prisões no ordenamento jurídico brasileiro e o HC n. ${ }^{\circ}$ 126.292/SP. Conclusão. Referências

\section{INTRODUÇÃO}

Desde o começo da década atual o Brasil vem passando por momentos turbulentos na política e na economia, com reflexos sociais importantes. Os desacertos das políticas econômicas, a crise econômica internacional, a corrupção que passou a ser investigada inicialmente no caso do Mensalão e agora na Operação Lava Jato, que, em março de 2016, completou dois anos, e o acirramento dos conflitos políticos, que têm especial relação com os problemas econômicos e, sobretudo, com o desvendamento da institucionalização da corrupção no estado brasileiro e as reações ao seu combate, vêm produzindo um sério quadro de crise política, econômica e, especialmente, de fundo ético.

Se por um lado o país esteve, não raras as vezes, ao longo de sua história às voltas com crises econômicas e/ou também com crises de natureza política, além das crises sociais propriamente, o que de fato não é novidade na história brasileira, por outro lado a crise pela qual passamos nesse início da década de 2010 é bastante diferenciada. Estamos vivenciando uma crise eminentemente de fundo ético, que está especialmente relacionada com as descobertas realizadas no âmbito da Operação Lava Jato, a qual foi deflagrada em Curitiba, inicialmente, para investigar um pequeno esquema de lavagem de dinheiro, e que hoje vem desbaratando aquele que, sem dúvida, constitui o maior esquema de corrupção da história institucional do Brasil ${ }^{1}$.

A intolerância social crescente em relação à impunidade que sempre beneficiou as elites brasileiras, nunca ao alcance das leis penais e processuais penais, exceto como vítimas, e os esquemas de desvio de dinheiro público e de pagamento de propinas descobertos antes no caso do Mensalão e agora pela Lava Jato, todos noticiados, divulgados e discutidos, sobretudo, por meio das redes sociais, inclusive tendo sessões de julgamento televisionadas, deixam clarividente o fato de que a corrupção é, hoje, acima de tudo, socialmente insustentável no Brasil, especialmente porque estamos tratando de um país de desigualdades gritantes e de um estado tributariamente voraz.

No Brasil, o que emergiu com o caso do Mensalão e mais profundamente com o caso da Lava Jato foi a captura de parte importante do estado por pessoas que exercem o poder político, empresas contratantes com os entes públicos e empresários(as), fato que tem como origem o modelo de financiamento de campanha eleitoral desenhado no Texto Constitucional e a velha confusão entre o público e o privado no país.

\footnotetext{
${ }^{1}$ Sobre o agravamento da crise brasileira nos últimos cinco anos, Lamounier (2016) faz importante análise, quando afirma que há um aspecto saudável nessa crise profunda.
}

Revista de Direito Brasileira | São Paulo, SP | v. 16 | n. 7 | p. 21 - 42 | Jan./Abr. 2017 
De qualquer sorte, a repercussão que os casos de corrupção no país têm ganhado nas redes sociais e nos mais diversos meios de comunicação evidencia o fato de que manter as elites alheias à justiça criminal, quando estão de modo sério e profundo envolvidas com o desvio de recursos públicos, não é mais admissível, pois enquanto sobram recursos públicos para serem desviados, a saúde pública, a educação pública e a segurança pública arrastam-se em estado terminal, atingindo antes de tudo a parcela mais pobre da sociedade, que é aquela que mais necessita desses serviços, e também os(as) contribuintes, que podem até deles necessitar menos, mas que não toleram mais pagar a conta da corrupção.

É nesse contexto que, tendo em vista a publicação no DJE em 17/05/2016 do Acórdão lavrado no HC n. ${ }^{\circ}$ 126.292/SP, julgado pelo Plenário do Supremo Tribunal Federal em 17 de fevereiro de 2016, interessa-nos aqui compreender em que medida pode se dar a relação entre as crises e os direitos e garantias fundamentais, que são o pilar do estado democrático de direito, e que possuem centralidade no ordenamento jurídico brasileiro.

Desse modo buscamos verificar, ao apreciarmos as possíveis relações que o julgamento do HC n. ${ }^{\circ}$ 126.292/SP guarda com a crise brasileira atual, se de alguma forma a decisão da Corte Suprema brasileira tangenciou direitos ou garantias fundamentais, ao possibilitar a tutela antecipada penal $^{2}$, a partir de uma reinterpretação do princípio da presunção de não culpabilidade, de não culpa ou de inocência ${ }^{3}$, e, finalmente, se assim atuou o Supremo Tribunal Federal - STF, pretendemos entender se o fez de modo satisfatoriamente justificado.

\section{O ORDENAMENTO JURÍDICO BRASILEIRO E AS CRISES}

Antes de tudo é importante pontuarmos a etimologia do substantivo crise. Segundo o Dicionário Houaiss Eletrônico, a palavra crise vem de crisis no latim, significando o momento de decisão, de mudança súbita, e de krísis no grego, que significa ação ou faculdade de distinguir, decisão, momento difícil. Relacionada à medicina também, a palavra crise significa o momento decisivo da doença, em que poderá evoluir para a cura ou para a morte, enquanto na economia a palavra liga-se à ideia de período de transição de um momento e prosperidade para um outro de depressão ou o contrário.

No âmbito do Direito as crises passaram a ser objeto da doutrina e do trabalho de pesquisa científica mais recentemente, quando assistimos ao fortalecimento da ideia de jurisprudência da crise $^{4}$, termo que vem ganhado espaço, especialmente, entre os

\footnotetext{
${ }^{2}$ Tendo em conta o fato de que no ordenamento jurídico brasileiro temos a prisão no curso da investigação ou do processo de natureza cautelar e a prisão com natureza jurídica de pena, é importante considerarmos aqui, por rigor técnico, que, em que pese o entendimento de autores como Sánchez (2002), para quem a antecipação da tutela penal é representada pelos delitos de perigo abstrato e de perigo concreto, pela punição de atos preparatórios e pela punição da tentativa, frutos de decisões políticas que são, em termos processuais propriamente, falamos aqui em antecipação da tutela penal quando a tutela penal definitiva, que é a tutela almejada, ou seja, a aplicação da(s) pena(s) prevista(s) para o delito, é dada antes do final do processo, provisoriamente.

${ }^{3}$ Ressaltamos que, ainda hoje, há doutrinadores como Luiz Flávio Gomes (1998) que preferem denominar o princípio em comento como sendo princípio da presunção de inocência apenas, porquanto, historicamente, o princípio da presunção de não culpabilidade foi utilizado pelo fascismo italiano em sua crítica à possibilidade de se presumir inocente o réu, quando, então, a presunção de não culpabilidade estava relacionada a uma situação de neutralidade do acusado, nem culpado nem inocente. Sucede que, como em ambos os casos, o acusado não pode ser tratado como culpado, primeiramente, porque a pretensa neutralidade de fato não existe, tendo em conta que a pessoa não é presumida culpada por ser tida como inocente até o trânsito em julgado, segundo Torres (1993) ou o duplo grau de jurisdição, e, segundamente, porque a Constituição de 1988 não menciona semanticamente a presunção de inocência, pois diz que ninguém será considerado culpado até o trânsito em julgado de sentença penal condenatória, não havendo, assim, prejuízo algum no uso do nome princípio da presunção de não culpabilidade no direito brasileiro, quando importa realmente entender o que vem a ser esse princípio.

${ }^{4}$ Esse tema pode ser estudado por meio de autores como Urbano (2014).
}

Revista de Direito Brasileira | São Paulo, SP | v. 16 | n. 7 | p. 21 - 42 | Jan./Abr. 2017 
doutrinadores(as) portugueses(as), que demonstram preocupação em refletir, sobretudo, acerca da jurisprudência do Tribunal Constitucional daquele país no período de sua última crise.

Na Constituição da República, as crises foram contempladas por meio de um sistema constitucional de crises que inclui o estado de sítio, o estado de defesa e a afetação de direitos e de garantias individuais. Há, assim, mecanismo constitucional para casos de iminente instabilidade institucional e também para casos de calamidades naturais de grandes proporções, o estado de defesa. De mesmo modo, existe mecanismo igualmente constitucional para o caso de comoção de grande repercussão nacional, no caso de não serem eficazes as medidas adotadas no estado de defesa; na hipótese de declaração do estado de guerra ou quando o estado brasileiro deve responder à agressão estrangeira armada, que é o estado de sítio.

Temos, portanto, mecanismos constitucionais para os casos em que pode ser necessário realizar a defesa do estado e das instituições democráticas. Todavia, longe desses momentos em que as crises afetam ou colocam em risco o estado e as instituições democráticas, as crises podem ocorrer, sem que tenham essa dimensão, quando, então, apesar do abalo de natureza social, política e/ou econômica, com reflexos sociais, evidentemente, as instituições democráticas se mantêm íntegras e o estado não corre perigo.

Ocorre que, em ambos os casos em que há uma crise, os direitos e garantias fundamentais parecem ser atingidos de algum modo, tanto que, para os casos graves em que a defesa do estado e das instituições democráticas se faz imprescindível, as hipóteses em que os direitos e garantias fundamentais são tangenciados estão expressamente previstas no Texto Constitucional.

É, dessa feita, perfeitamente possível concebermos que os direitos e as garantias fundamentais possam ser impactados pelo fenômeno da crise, o que pode ser revelado, inclusive, na jurisprudência e na atividade legiferante, circunstâncias essas que mais dizem respeito aos que se ocupam do Direito.

Por esse motivo é que nos interessa aqui compreender em que medida pode se dar a relação entre as crises e os direitos e garantias fundamentais, quando o estado e as instituições democráticas não correm perigo, oportunidade em que pretendemos analisar criticamente, ainda no calor dos acontecimentos, quando o acórdão praticamente acabou de ser publicado, em que medida o julgamento do referido $\mathrm{HC}$ n. ${ }^{\circ}$ 126.292/SP tem alguma relação com a crise brasileira atual, oportunidade em que apreciaremos, ademais, se de algum modo essa importante decisão da Corte Suprema brasileira tangenciou direitos ou garantias fundamentais, e, por fim, se assim atuou, se o fez de maneira satisfatoriamente justificada.

Portanto, neste trabalho em que se leva em consideração o fato de que, por maioria de votos, ou seja, por 7 (sete) a 4 (quatro), o Supremo Tribunal Federal passou novamente a admitir a tutela antecipada penal, a metodologia adotada consiste em realizar uma análise crítica dos fundamentos contidos no voto do Relator do $\mathrm{HC} \mathrm{n} .^{\circ}$ 126.292/SP, o voto vencedor, quando será feita uma análise conceitual do princípio da não culpabilidade, abordando, também, as disciplinas da prisão e da antecipação da tutela penal em nível infraconstitucional no sistema jurídico brasileiro, a fim de entendermos em que medida a mudança de orientação do Supremo Tribunal Federal sobre o momento do início do cumprimento da pena afetou garantia fundamental e, também, se tal fato guardaria, ademais, relação com a crise especialmente política que atinge o Brasil.

\section{O HC N. ${ }^{\circ}$ 126.292/SP DO STF}

Repercutiu nacionalmente a decisão do Supremo Tribunal Federal proferida no dia 17 de fevereiro de 2016, em sede de Habeas Corpus, o HC n. ${ }^{\circ}$ 126.292/SP, quando, por maioria de votos, precisamente por 7 (sete) a 4 (quatro), foi negado o Habeas Corpus pela Corte Suprema do país, sob o argumento de que a execução provisória de acórdão penal condenatório proferido em 
grau de apelação, ainda que sujeito a recurso especial ou extraordinário, não compromete o princípio constitucional da presunção de inocência afirmado pelo artigo $5^{\circ}$, inciso LVII, da Constituição da República, quando a sentença penal condenatória foi confirmada pelo segundo grau, restando admitida, assim, a execução provisória da pena.

No HC n. ${ }^{\circ}$ 126.292/SP, que tratou basicamente do momento do início do cumprimento da pena e do princípio da presunção de não culpabilidade, o Supremo Tribunal Federal decidiu que o início do cumprimento da pena pode ocorrer a partir da confirmação da sentença penal condenatória pelo segundo grau de jurisdição, o que não confrontaria o princípio da presunção de não culpabilidade, porquanto, quando o tribunal mantém a condenação, é encerrada a análise dos fatos e das provas que atuaram na formação da culpa, possibilitando o início da execução da pena.

Analisando o Acórdão, depreende-se do voto do Relator que o princípio da presunção de inocência ou da não culpabilidade deve encontrar limites a partir da confirmação da sentença condenatória pelo segundo grau de jurisdição, tendo em vista que os recursos destinados ao Superior Tribunal de Justiça e ao Supremo Tribunal Federal não servem à rediscussão de fatos e de provas, versando sobre matéria de direito, sendo que, exceto quando se trata de revisão criminal, o exame de provas e dos fatos somente se dá nas vias ordinárias.

Nesse sentido, como reforço de argumentação tem-se no voto do Relator a menção ao fato de que a presunção de inocência para efeito da Lei da Ficha Limpa ${ }^{5}$, Lei Complementar n. ${ }^{\circ}$ 135/2010, tal como previsto na lei e definido pelo STF, já não impedia, antes do trânsito em julgado, que a condenação do candidato servisse como causa de inelegibilidade.

Enquanto argumento também consta do voto do Relator que a Emenda Constitucional n. ${ }^{\circ} 45$ de 2004, ao dispor sobre os recursos extraordinários, exigiu a presença de repercussão geral, o que ultrapassa o mero interesse entre as partes do processo, sem se esquecer do fato de que os recursos extraordinários não possuem, em regra, efeito suspensivo.

Além disso, argumentou o Relator que há precedentes que corroboram seu entendimento, a exemplo do que ocorre com o $\mathrm{HC} \mathrm{n} .^{\circ}$ 85.886/RJ, da relatoria da Ministra Ellen Gracie $^{6}$, que menciona, aliás, precedentes no sentido de compreender a presunção de nãoculpabilidade apenas como a impossibilidade de se presumir a culpa, que deve ser provada pelo órgão da acusação, e não pelo acusado.

Apontou também o Relator que seu entendimento não impede o manejo de medidas cautelares e do Habeas Corpus, de modo que concluiu pela denegação do Habeas Corpus, que objetivava impedir a execução provisória da pena, tendo sido seguido pelos ministros Gilmar Mendes, Cármen Lúcia, Luiz Fux, Luís Roberto Barroso e Edson Fachin, ao passo que os Ministros Ricardo Lewandowski, Celso de Mello, Marco Aurélio e Rosa Weber votaram pela concessão de Habeas Corpus, no sentido da manutenção da jurisprudência do STF que exige o trânsito em julgado para cumprimento de pena.

\footnotetext{
${ }^{5}$ Apesar do que consta do voto do Relator do $\mathrm{HC}$ n. ${ }^{\circ}$ 126.292/SP, é pertinente lembrarmos que o alcance do princípio da não culpabilidade na Lei da Ficha Limpa não conduz à aplicação de sanção penal, tal como ocorre no processo penal. Nessa lei, que diz respeito às inelegibilidades, não estamos diante de um caso em que devemos considerar o candidato culpado, porque o que ocorre é que o candidato apenas deve ser reconhecido como não detentor de perfil adequado para exercer função de mandatário, sendo que a inelegibilidade não constitui uma forma de repressão, não tendo natureza jurídica de sanção penal ou administrativa.

${ }^{6}$ A esse respeito, tendo em vista o que foi discutido no $\mathrm{HC} \mathrm{n.}{ }^{\circ} 85.886 / \mathrm{RJ}$, impõe mencionarmos que são poucas as constituições dos estados que adotam o sistema do trânsito em julgado para a superação da presunção de não culpabilidade, sendo essas, especialmente, a Constituição da Albânia de 1998; a Constituição de Angola de 2010; a Constituição da Bulgária de 1991; a Constituição da Croácia de 1991; a Constituição da República Dominicana de 2010; a Constituição do Equador de 2008; a Constituição da Itália de 1947; a Constituição da Polônia de 1997; a Constituição de Portugal de 1976; a Constituição da Romênia de 1991. Como podemos notar, são estados menos desenvolvidos, à exceção da Itália onde, ainda assim, a corrupção assola o país. Dados disponíveis em 〈https://www.constituteproject.org/?lang=en >. Acesso em: 02 março de 2016.
}

Revista de Direito Brasileira | São Paulo, SP | v. 16 | n. 7 | p. 21 - 42 | Jan./Abr. 2017 
A decisão ora tratada indica o início de uma importante mudança no entendimento da Corte Suprema do país a respeito da presunção de não culpabilidade e, portanto, uma possível virada em sua jurisprudência, tendo em conta que, desde 2009, no julgamento da HC n. ${ }^{\circ} 84.078$ 7/MG, da relatoria do Ministro Eros Grau, ficou condicionado o início do cumprimento da pena ao trânsito em julgado da sentença condenatória, embora tenha sido ressalvada a constitucionalidade da prisão cautelar.

Antes de 2009, contudo, a jurisprudência do Supremo Tribunal Federal admitia o início da execução da pena sem o trânsito em julgado da sentença ${ }^{7}$, sendo que naquele momento ainda conviviam com a Constituição e o princípio da presunção de não culpabilidade nela esculpido dispositivos do Código de Processo Penal cuja recepção não havia sido analisada judicialmente em face da nova ordem constitucional.

$\mathrm{Na}$ verdade, em termos legislativos, foi a partir de 2008 que alguns dispositivos do Código de Processo Penal referentes ao disciplinamento do instituto da prisão foram sendo revogados expressamente, enquanto outros passaram a ser considerados revogados tacitamente, sobretudo por parte da doutrina, contexto esse em que ainda subsistia intocável o velho art. 105 da Lei de Execução Penal, que data de 1984.

No julgamento do HC n. ${ }^{\circ}$ 84.078-7/MG, portanto, o STF modificou sua jurisprudência, curiosamente por 7 (sete) votos a 4 (quatro), tal como agora ocorre com o HC n. ${ }^{\circ}$ 126.292/SP.

Até 2009, portanto, apesar do art. 5.․, inciso LVII, da Constituição de 1988, sem falarmos do art. 105 da Lei de Execução Penal de 1984, a jurisprudência pátria entendia que a condenação confirmada pelo tribunal demonstrava o marcado juízo de consistência da acusação, que possibilitava o início do cumprimento da pena de prisão como consequência natural da condenação, de sorte que o princípio da presunção de não culpabilidade não inibia a execução provisória da pena imposta, ainda que pendentes de julgamento os recursos extraordinários.

No caso do HC n. ${ }^{\circ}$ 126.292/SP, esse remédio constitucional foi impetrado em face de decisão do Superior Tribunal de Justiça que indeferiu o pedido de liminar em HC lá anteriormente impetrado. Trata-se de um Habeas Corpus interposto por pessoa comum, de origem pobre, que foi condenada à pena de 5 (cinco) anos e 4 (quatro) meses de reclusão pelo crime previsto no art. 157, caput, § 2. ${ }^{\circ}$, do Código Penal. Condenado o réu em primeiro grau, a defesa apelou, sendo o recurso improvido, quando o Tribunal de Justiça de São Paulo determinou a expedição de mandado de prisão. Esse mandado de prisão, contudo, foi considerado, segundo a defesa do réu, uma afronta ao princípio da presunção de não culpabilidade e também à jurisprudência do Supremo Tribunal Federal.

\section{A CRISE BRASILEIRA: O CONTEXTO HISTÓRICO EM QUE SE INSERE O HC N. 126.292/SP}

A análise do inteiro teor do Acórdão lavrado no HC n. ${ }^{\circ}$ 126.292/SP indica uma possível guinada na jurisprudência do Supremo Tribunal Federal, o que somente poderá ser confirmado, efetivamente, com o decurso do tempo.

Discussão à parte sobre a superação e também a respeito da vinculação dos precedentes ${ }^{8}$, que são temas mais do que nunca atuais por força do novo Código de Processo Civil ${ }^{9}$, em vigor

\footnotetext{
7 Contudo, não podemos desprezar o fato de que, mesmo antes da reforma do CPP promovida pela Lei n. ${ }^{\circ}$ 11.719/2008 e da decisão do STF no HC n. ${ }^{\circ}$ 84.078-7/MG, alguns julgados reconheciam o direito de apelar em liberdade, com fundamento no Pacto de São José da Costa Rica. Nesse sentido citamos o HC n. ${ }^{\circ} 88.420$ (rel. Min. Ricardo Lewandowski) do STF e o Enunciado de Súmula 347 do STJ.

${ }^{8} \mathrm{O}$ tema dos precedentes, por si só, daria um trabalho, porque seria possível discutir se foi assegurado ao menos um diálogo respeitoso entre o que o próprio STF já decidiu no passado sobre a antecipação de tutela e o caso que estava em julgamento no HC n. ${ }^{\circ}$ 126.292/SP.
} 
desde 18 de março de 2016, é possível aqui vislumbrarmos relação entre a grave situação de crise pela qual passa o Brasil e a decisão do STF no HC n. ${ }^{\circ}$ 126.292/SP sobre a antecipação da tutela penal não só pela justificação do Relator como também pelo contexto histórico em si no qual foi produzida a decisão.

Nesse sentido é pertinente vislumbrarmos a preocupação crescente por parte de juízes e Ministros do STF com os reclamos da sociedade pelo combate à corrupção e pelo fím da impunidade que emergiram no país primeiramente com o julgamento do caso do Mensalão e, nos últimos dois anos, com os resultados surpreendentes da Operação Lava Jato ${ }^{10}$.

A gravidade dos crimes praticados por pessoas que exercem cargos políticos e empresários(as) investigados(as) pela Lava Jato, vários dos quais já condenados em primeiro grau de jurisdição, e a certeza de que a pena somente será cumprida com o trânsito em julgado são, evidentemente, uma preocupação dos órgãos de investigação, do Ministério Público, que investiga também e é titular da ação penal, e dos órgãos do Judiciário. Isso porque, se por um lado as mudanças ocorridas no âmbito do processo penal nos últimos anos possibilitaram a tramitação menos morosa das ações penais até a fase da sentença, por outro lado a certeza de que os réus poderão cumprir as penas somente após o trânsito em julgado, o que significa que poderão passar mais de uma década livres até esgotarem todos os recursos extraordinários, sem que tenham que ser recolhidos à prisão, é algo que, diante da corrupção que tomou conta do estado brasileiro, incentiva a prática permanente de crimes de colarinho branco, produz indignação, gera manifestações sociais, e, ademais, evidencia nossa convivência quase amistosa com a impunidade, sem falarmos nos danos causados ao erário num estado em que os recursos públicos sempre foram escassos.

A atual intolerância de parte considerável da sociedade brasileira à corrupção, aos corruptos e aos corruptores, de que nos fala Sarah $^{11}$ (2015) tem sido fomentada enormemente pela publicização em cadeia nacional de televisão dos julgamentos no STF e pela força das redes sociais, que, por sua vez, tem produzido manifestações populares gigantescas pelas ruas do país, desde que o primeiro caso sério de corrupção envolvendo os principais políticos que se encontravam no governo e seus apoiadores veio à tona, tendo ficado notório e internacionalmente conhecido como Mensalão.

Do Mensalão até o presente momento, a intolerância da sociedade à corrupção vem crescendo consideravelmente, e os(as) brasileiros(as) passaram a clamar pela punição daqueles(as) que detêm poder político, das empresas e dos(as) empresários(as) envolvidos(as) com campanhas eleitorais financiadas por caixa 2 e com desvios de recursos da maior empresa brasileira, a Petrobras, que se materializaram no pagamento de propinas milionárias a políticos de partidos diversos. E isso não é tudo, porquanto não podemos nos esquecer de que a corrupção vem sendo investigada em outros setores do governo federal, como no CARF, ligado ao Ministério da Fazenda, por meio da Operação Zelotes.

A decisão do STF no HC n. ${ }^{\circ}$ 126.292/SP interrompe, portanto, neste momento, a jurisprudência que se consolidou desde o julgamento do $\mathrm{HC}$ n. ${ }^{\circ}$ 84.078-7/MG, em 2009, quando

\footnotetext{
${ }^{9}$ A respeito da aplicação do NCPC ao CPP, diante do silêncio daquele código, diz Cássio Scarpinella Bueno (2015, p. 52) que: "A questão, pertinentíssima, é saber se, não obstante esse silêncio, a aplicação continua a ser autorizada pelo art. $3 .^{\circ}$ do CPP. A melhor resposta parece ser a positiva, o que se justifica até mesmo pela amplitude do texto da referida regra processual penal. De resto, nos casos em que o Código de Processo Penal faz expressa remissão ao Código de Processo Civil (art. 139 [depósito e administração de bens arrestados]; art. 362 [citação por hora certa]; e art. 790 [homologação de sentença estrangeira]), é irrecusável o prevalecimento da disciplina trazida pelo novo CPC".

${ }^{10}$ Para tanto, vejamos: < http://oglobo.globo.com/brasil/condenados-podem-ser-presos-apos-sentenca-em-2-instanciadecide-stf-18694995>.

11 Disponível em $<$ http://politica.estadao.com.br/blogs/gestao-politica-e-sociedade/politica-e-sociedade-asmanifestacoes-de-rua-de-2013-e-2015/>. Acesso em: 23 de março de 2016.
}

Revista de Direito Brasileira | São Paulo, SP | v. 16 | n. 7 | p. 21 - 42 | Jan./Abr. 2017 
a Corte Suprema do país decidiu que o início do cumprimento da pena dependia do trânsito em julgado da sentença condenatória, sob pena de ofensa ao princípio da presunção da inocência.

No citado Acórdão do $\mathrm{HC}$ n. ${ }^{\circ}$ 84.078-7/MG ficou decidido que

(...) nas democracias mesmo os criminosos são sujeitos e direitos. (...) É inadmissível a sua exclusão social, sem que sejam consideradas, em quaisquer instâncias, as singularidades de cada infração penal, o que somente se pode apurar plenamente quando transitada em julgado a condenação de cada qual. ${ }^{12}$

É forçoso observarmos aqui que a crise atual brasileira tem contornos realmente muito sérios, que podem ser vislumbrados na politização da população, e que, evidentemente, deita raízes no financiamento eleitoral, no sistema eleitoral como um todo e, de modo mais específico, nas formas de acesso ao poder político.

Em 2014, aliás, o Professor Mangabeira Unger (2014) declarou que o modelo econômico brasileiro já se encontrava esgotado, e que no Brasil impera o discurso da Suécia Tropical, segundo o qual queremos gozar de benefícios sem que passemos antes pela conquista desses. Diz o Professor de Harvard, que, por aqui, almejamos ter acesso ao poder político e a oportunidades econômicas sem termos antes lutado para tanto.

Essa afirmação de Unger remete-nos a Holanda (2015, p. 50), quando, ao se referir ao perfil aventureiro daqueles que colonizaram o Brasil, contrapondo esse ao perfil de trabalhador, afirma que o ideal dos aventureiros era colher frutos sem que tivessem plantado árvores.

Devemos acrescentar que, no Brasil atual, país que experimenta uma de suas mais sérias crises políticas e econômicas, com grave quadro de recessão e de aumento do desemprego, é bastante clarividente que, além da corrupção institucionalizada e dos problemas de acesso ao poder político e de oportunidades políticas, o modelo de Welfare State adotado pelo constituinte de 1988 e as demandas geradas a partir desse modelo pelos(as) cidadãos(ãs), após a promulgação da Constituição, também compõem o quadro que gerou a crise econômica e também a crise política.

Nesse modelo de estado que apresenta sinais de esgotamento não só em razão das excessivas demandas sociais como da escassez de recursos, os direitos sociais vêm imediatamente à tona, porquanto são os primeiros a serem atingidos. As demandas da população por direitos sociais, num país de extrema desigualdades sociais e econômicas, muitas vezes materializadas em demandas judiciais que veiculam direitos coletivos como se individuais fossem, aliadas ao fato de que o legislativo não consegue formar consensos ainda que temporários para decidir, por meio da atividade legislativa, os temas mais caros à população são componentes poderosos da crise brasileira, devendo considerarmos nesse quadro o fato de que temos uma Constituição extremamente generosa na concessão de direitos fundamentais por meio de normas jurídicas amplas e vagas.

Nesse caminho, Claus Offe (1995, p. 271) faz uma crítica ao estado de bem-estar, dizendo que, assentado no estado de direito, na democracia representativa e em políticas públicas que objetivam assegurar o bem-estar dos(as) cidadãos(ãs), nesse modelo de estado podem ser constatados problemas especialmente relacionados à ligação entre o liberalismo e as políticas de bem-estar.

Buscando identificar o que permite que as democracias capitalistas que adotam o bemestar social tornem-se desorganizadas, sem desprezar as contradições do estado de bem-estar Offe (1995) segue afirmando que esse estado se tornou uma atividade econômica de alto custo para o próprio governo, sendo que o modelo do estado do bem-estar padece em decorrência da ausência de sintonia entre a sociedade que demanda cada vez mais e as exigências do mercado liberal.

${ }^{12}$ Disponível em <http://www.stf.jus.br/arquivo/cms/noticiaNoticiaStf/anexo/ementa84078.pdf>. Acesso em: $28 \mathrm{de}$ março de 2016.

Revista de Direito Brasileira | São Paulo, SP | v. 16 | n. 7 | p. 21 - 42 | Jan./Abr. 2017 
Estejamos ou não vivendo a crise final do estado de bem-estar - o que não constitui objeto do presente trabalho discutir - acirrada no Brasil pela real institucionalização da corrupção, por sérios problemas de acesso ao poder político e, também, de oportunidades econômicas, o fato é que a mudança que parece ocorrer na orientação do Supremo Tribunal Federal sobre o princípio da presunção de não culpabilidade está bastante contextualizada historicamente como produto mesmo deste momento de séria crise brasileira. E, nesse momento, aliás, é a sociedade que vem sinalizando que não pretende ver os condenados na Operação Lava Jato soltos até o trânsito em julgado da sentença, que, no país, ocorre em média no prazo de dez anos.

Nesse sentido, é importante a esta altura apontarmos que foi a partir da Lei Fundamental de 1949 na Alemanha, que teve início o processo de constitucionalização do Direito, quando o Tribunal Constitucional Federal, fundamentado na doutrina que já havia se desenvolvido, firmou o entendimento de que os direitos fundamentais possuíam dupla dimensão, a subjetiva, que serve à proteção de situações individuais, e a objetiva, que se materializa na instituição de uma ordem objetiva de valores, de sorte que o sistema jurídico deve proteger certos direitos e valores (SAMPAIO, 2006, p. 114).

Essa constitucionalização do Direito no Brasil, por sua vez, teve início bem mais tarde, em 1988, a partir do advento da Constituição da República, quando direitos e garantias fundamentais ganharam evidente centralidade no ordenamento jurídico.

E no rol de direitos e garantias fundamentais presente no Texto Constitucional, uma importante garantia individual expressamente prevista na Constituição de 1988 é a presunção da inocência, de não culpabilidade ou de não culpa, que, anteriormente, à míngua de previsão expressa, era interpretada por alguns como decorrência do princípio do devido processo legal.

O princípio da presunção de não culpabilidade, que aqui nos interessa enquanto garantia fundamental, está na Constituição da República previsto no art. 5. ${ }^{\circ}$, inciso LVII, onde está disposto que ninguém será considerado culpado até o trânsito em julgado de sentença penal condenatória.

Tradicionalmente, na doutrina brasileira o princípio da presunção de inocência é entendido sob três distintos enfoques. Assim, ele é compreendido como garantia política que faz com que todas as questões ligadas ao estado de liberdade devam ser interpretadas em favor do acusado; como norma probatória, de sorte que o acusado é presumidamente inocente, devendo o acusador provar sua culpa, pois, caso contrário, se restar dúvida, ele deve ser absolvido (in dubio pro reo); e, ainda, como norma de tratamento, o que significa que, se o acusado é presumido inocente, ele deve ser tratado como inocente, circunstância que impede medidas contrárias a esta presunção, fazendo com que responder ao processo em liberdade seja a regra (ARANTES FILHO, 2010, p. 24).

Essa interpretação da presunção de inocência aliada a diversas questões relacionadas ao processo e especialmente ao sistema recursal, no Brasil, têm produzido efeitos práticos nefastos e feito com que a justiça criminal seja perfeitamente qualificada como desigual. Por aqui, é de conhecimento público e notório o fato de que os que cometem crimes e podem pagar por advogados(as) qualificados(as) aguardam aproximadamente uma década para que ocorra o trânsito em julgado, sem prejuízo de que aconteça o fenômeno da prescrição em uma de suas formas neste período. Já as pessoas pobres, sem instrução, geralmente representadas por defensores(as) públicos(as) lotados(as) de processos, muitas vezes nem recorrem ao Tribunal de segundo grau. Assim, a sensação de impunidade só aumenta no país.

\section{O PRINCÍPIO DA PRESUNÇÃO DE NÃO CULPABILIDADE, A DISCIPLINA DAS PRISÕES NO ORDENAMENTO JURÍDICO BRASILEIRO E O HC N. ${ }^{0}$ 126.292/SP}

Conhecido também como princípio do estado de inocência ou princípio da presunção de inocência, o princípio da presunção de não culpabilidade foi modernamente previsto na 
Declaração dos Direitos dos Homens e dos Cidadãos de 1789. Tal fato significou uma reação ao sistema processual penal inquisitório, que deitava raízes no direito canônico e vigorava desde o século XII, período em que o que se presumia era a culpa do acusado.

Fruto do Iluminismo, a presunção de não culpabilidade ganhou destaque, séculos mais tarde, precisamente no ano de 1948, na Declaração dos Direitos Humanos, da ONU. Ademais, o princípio foi previsto na Convenção Europeia sobre Direitos Humanos (art. 6.2, 1950), no Pacto Internacional de Direitos Civis e Políticos (art. 14.2, 1966), na Convenção Americana sobre Direitos Humanos - Pacto de São José da Costa Rica (art. 8., I e II, 1969), e na Carta dos Direitos Fundamentais da União Europeia (art. 48), documento mais recente, datado do ano 2000, segundo a qual "Todo o arguido se presume inocente enquanto não tiver sido legalmente provada a sua culpa".

Com previsão expressa na Constituição de 1988 do princípio segundo o qual ninguém é considerado culpado até o trânsito em julgado da sentença penal condenatória, é preciso notarmos, de antemão, que, historicamente, na jurisprudência do STF não houve apenas um entendimento daquela Corte acerca da abrangência desse princípio, ao que devemos acrescentar o fato de que, no ordenamento jurídico brasileiro, convivem dois textos distintos referentes à presunção de inocência.

Nesse sentido, se por um lado na Constituição está dito no art. $5^{\circ}{ }^{\text {, inciso LVII, que }}$ "ninguém será considerado culpado até o trânsito em julgado de sentença penal condenatória", por outro lado o art. 8. ${ }^{\circ}, 2$, do Pacto de São José da Costa Rica (Convenção Interamericana de Direitos Humanos), prescreve que "Toda pessoa acusada de um delito tem direito a que se presuma sua inocência, enquanto não for legalmente comprovada sua culpa”, optando, como se depreende das letras do referido dispositivo, pelo sistema do duplo grau de jurisdição para a superação da presunção de inocência.

No Sistema Interamericano de Direitos Humanos, aliás, um dos principais instrumentos que dele faz parte é a Convenção Interamericana de Direitos Humanos, a qual, válida no Brasil desde 1992, convive no ordenamento jurídico pátrio com a Constituição de 1988, que previu expressamente, como dito antes, que "ninguém será considerado culpado até o trânsito em julgado da sentença penal condenatória".

Nossa Constituição, portanto, adotou expressamente o sistema segundo o qual, para que se possa superar a presunção de não culpabilidade, é preciso o trânsito em julgado, indo além do que foi previsto no Pacto de São José da Costa Rica, que aderiu ao sistema de superação da mencionada presunção de não culpabilidade pelo duplo grau de jurisdição, como dito antes.

Quanto ao duplo grau de jurisdição propriamente, se por um lado a Constituição de 1988 permaneceu silente a respeito desse princípio, por outro lado ele está assegurado no Pacto de São José da Costa Rica, em seu art. 8. ${ }^{\circ}, 2$, h, nos seguintes termos: "Durante o processo, toda pessoa tem direito, em plena igualdade, às seguintes garantias mínimas: (...) direito de recorrer da sentença para juiz ou tribunal superior", ao que se soma o disposto no art. 25 do referido Pacto, quando prescreve que "Toda pessoa tem direito a um recurso simples e rápido perante juízes e tribunais competentes (...)".

Já o Pacto Internacional de Direitos Civis e Políticos, outro instrumento internacional que trata de direitos humanos e que ingressou em nosso ordenamento jurídico no ano de 1992, em seu art. 14.5 está previsto que "Toda pessoa declarada culpada de um delito tem direito a que a sentença condenatória e a pena sejam submetidas a um tribunal superior conforme o estabelecido pela lei".

Ocorre que nem o Pacto de São José da Costa Rica nem o Pacto Internacional de Direitos Civis e Políticos, que versam sobre direitos humanos, foram aprovados pelo quórum de emenda constitucional, conforme dispõe a Emenda Constitucional n. ${ }^{\circ}$ 45, a qual, ademais, é posterior aos indicados Pactos. Nesse caso, temos que considerar que, em 2008, o STF tratou da internalização dos tratados no Recurso Extraordinário n. ${ }^{\circ}$ 466.343/SP, quando, por 5 (cinco) 
votos a 4 (quatro), decidiu que tratados de direitos humanos, para terem status de norma constitucional, devem, de fato, ser aprovados pelo quórum de emenda à constituição, sob pena de terem status supralegal apenas. Quanto aos tratados internacionais de direitos humanos aprovados na sistemática anterior à prevista na EC n. ${ }^{\circ} 45 / 2004$, esses, diz o STF, possuem também status supralegal, isto é, situam-se abaixo da Constituição e acima da legislação ordinária.

No Brasil, portanto, hoje, os tratados de direitos humanos podem ser equivalentes às emendas constitucionais, desde que aprovados pelo Legislativo após a EC n. ${ }^{\circ}$ 45/2004 pelo quórum necessário para as emendas constitucionais; ou podem ter caráter supralegal (conforme entende o STF), se aprovados antes da referida Emenda ou, ainda que posteriormente, sem o quórum especial, quando estarão acima das normas infraconstitucionais, funcionando como paradigma de controle da produção normativa doméstica (BRANCO; MENDES, 2015, p. 595).

Isso é algo que interessa no caso da decisão proferida no $\mathrm{HC}$ n. ${ }^{\circ} 126.292 / \mathrm{SP}$, em razão do princípio da não culpabilidade, pois devemos considerar o fato de que o Pacto de São José da Costa Rica, de caráter supralegal e posterior à Constituição, trata do princípio exigindo apenas o duplo grau de jurisdição para superar a presunção de inocência, enquanto o Texto Constitucional exige para tanto o trânsito em julgado da sentença.

Além disso, o Pacto Internacional dos Direitos Civis e Políticos também não exige o trânsito em julgado da sentença para que haja a superação da presunção de inocência, chegando a estipular, no art. 14, 5, que "Toda pessoa declarada culpada por um delito terá direito de recorrer da sentença condenatória e da pena a uma instância superior, em conformidade com a lei".

No caso, ao decidir pelo progressivo esgotamento da presunção de não culpabilidade autorizador da execução antecipada da pena a partir da confirmação da sentença condenatória pelo segundo grau de jurisdição, o Ministro Relator do HC n. ${ }^{\circ}$ 126.292/SP, que nada diz em seu voto sobre os dois Pactos de Direitos Humanos acima mencionados, não fere o Pacto de São José da Costa Rica e também não atinge o Pacto Internacional dos Direitos Civis e Políticos, mas parece ferir os limites semânticos da Constituição da República, argumento que poderia ser enfrentado no voto do Relator por meio da ideia de mutação constitucional, quando ainda deveria tratar da questão dos limites da própria mutação constitucional, o que não ocorreu, optando o Relator, em seu voto, por demarcar o núcleo da norma jurídica da presunção de não culpabilidade.

Devemos pontuar, antes de tudo, que o Pacto de São José da Costa Rica convive perfeitamente com a Constituição da República, pois aquele não veda que os estados façam a opção pelo sistema de superação da presunção de não culpabilidade por meio do trânsito em julgado, sistema esse ainda mais favorável ao acusado, desde que o estado que assim o faça, tal como o Brasil, evidentemente não fira as normas contidas no Pacto sobre a presunção de inocência, lembrando, ademais, que no sistema brasileiro o Pacto de São José tem caráter apenas supralegal, segundo o Supremo Tribunal Federal. Nada disso, contudo, foi tratado no voto do Ministro Relator.

Sucede que, em que pese a análise do inteiro teor do Acórdão não seja o objetivo do presente trabalho, é forçoso reconhecer que em seu voto do Ministro Luís Roberto Barroso ${ }^{13}$ enfrenta o fenômeno da mutação constitucional, quando constata a sua ocorrência em 2009 e, também, em 2016, sendo essa derradeira decorrente do "impacto traumático da própria realidade que se criou após a primeira mudança de orientação”, diz o referido Ministro.

\footnotetext{
${ }^{13}$ Uma discussão que não é objeto do presente trabalho, mas que tangencia seu objeto e por isso merece menção, sem dúvida, diz respeito à ratio decidendi contida na decisão do STF que é aqui tratada, o que possibilitaria inúmeras discussões referentes à identificação dos precedentes e também à estrutura e a formatação dos textos das decisões dos tribunais brasileiros, as quais se materializam pelo modelo seriatim ao invés do modelo per curiam. Certo é, pelo menos naquilo que ao trabalho atual interessa, que, mais do que adotado pela maioria, para ser ratio decidendi um fundamento deve ter sido discutido por todos os julgadores, o que significa que precisa ter sido colocado de modo explícito à discussão de todos os membros do órgão colegiado.
}

Revista de Direito Brasileira | São Paulo, SP | v. 16 | n. 7 | p. 21 - 42 | Jan./Abr. 2017 
Além do mais, analisando o julgamento do $\mathrm{HC}$ n. ${ }^{\circ}$ 126.292/SP, é necessário reconhecermos no voto do Relator que a legislação infraconstitucional não foi enfrentada, ao passo que, para ser superada, deveria ter sua inconstitucionalidade reconhecida, o que igualmente não aconteceu, de modo que o art. 283, caput, do CPP, que teve sua redação modificada por lei em 2011, não foi sequer simplesmente considerado.

Aqui mais uma vez importa mencionar que se pode depreender do Acórdão em questão que somente o Ministro Barroso, quando votou pela antecipação da tutela penal, foi quem, ainda que sucintamente, argumentou que o art. 283 não impede a prisão após a confirmação da sentença condenatória pelo segundo grau, tendo em vista que não é a legislação infraconstitucional que deve orientar a interpretação da Constituição, pois é essa que deve orientar a interpretação daquela.

Não bastasse tanto, antes que possamos argumentar que a solução encontrada pelo STF no julgamento do Habeas Corpus n. ${ }^{\circ}$ 126.292/SSP foi a ponderação para o caso de colisão entre o princípio da presunção da não culpabilidade e a efetividade da função da jurisdição penal, devemos lembrar apenas que ponderação não é mera escolha, e que ponderação realmente não foi realizada pelo Relator, ao que somamos o fato de que a ponderação não poderia desconsiderar que o art. $5^{\circ}$, inciso LVII, em sua semântica, trata da superação da presunção de culpabilidade por meio do trânsito em julgado, o que deveria ser tratado pelo Ministro Relator.

Havemos de dizer, porém, mais uma vez, que o Ministro Barroso, em seu voto, quando se manifestou favoravelmente à prisão após a confirmação da prisão pelo segundo grau de jurisdição, ainda que sem o trânsito em julgado, foi o único que tratou da ponderação de princípios no caso em evidência. Disse o Ministro Barroso que no núcleo do princípio da presunção de inocência reside a ideia de que a imposição ao réu de medidas restritivas de direitos deve ser excepcional, de forma que, para tanto, é preciso que existam elementos probatórios justificadores da necessidade, da adequação e também da proporcionalidade em sentido estrito da medida extrema. Para o referido Ministro, outrossim, a Constituição de 1988 condiciona a culpabilidade ao trânsito em julgado da sentença penal condenatória e não a prisão, o que, devemos dizer, não foi abordado no voto do Relator. Assim, de acordo com o voto do Ministro Barroso, verifica-se a existência de tensão entre a presunção de inocência e o interesse da Constituição na efetividade da lei penal, em favor dos objetivos - prevenção geral e específica - e também de bens jurídicos - a vida, a dignidade humana, a integridade física e moral, dentre outros tutelados bens pelo direito penal. Estão, para o mencionado Ministro, em tensão a presunção de culpabilidade e esses valores, que estão previstos nos art. $5^{\circ}$, caput (direitos à vida, à segurança e à propriedade), e no inciso LXXVIII (princípio da razoável duração do processo), e no art. 144 (segurança), todos da Constituição.

Embora não seja objeto do presente trabalho apreciar o Acórdão integralmente, pois aqui buscamos analisar com profundidade os fundamentos contidos no voto do Ministro Relator, é, dessa feita, indispensável reconhecermos que nesse derradeiro não foi realizada ponderação, que, por sua vez, foi tratada no voto do Ministro Barroso, ainda que possamos discutir a ausência de demonstração dessa. Em seu voto, ademais, o Ministro Barroso ainda aborda o fundamento da ordem pública para a prisão após a confirmação da sentença penal condenatória pelo segundo grau de jurisdição, e também menciona a necessidade de proteção suficiente dos direitos fundamentais que decorre do princípio da proporcionalidade.

Neste ponto, quando analisamos os fundamentos contidos no voto do Relator, é pertinente lembrarmos que foi apenas a partir da década de 2000 que a disciplina das prisões no país sofreu efetivamente mudanças decorrentes da constitucionalização do direito processual penal. Nessa quadra da história surgiram, em 2008, as Leis Federais n. ${ }^{\circ} 11.689$ e n. ${ }^{\circ} 11.719$, e, em 2009, houve o julgamento da HC n. ${ }^{\circ}$ 84.078-7/MG, da relatoria do Ministro Eros Grau, a partir do qual a jurisprudência do STF a respeito da presunção de não culpabilidade foi alterada para não admitir a execução antecipada da pena. 
Até 2008, portanto, em que pese o art. 105 da Lei de Execução Penal, que data de 1984, e a Constituição de 1988, em seu art. 5. ${ }^{\circ}$, inciso LVII, além da prisão com natureza jurídica de sanção penal, tínhamos no sistema processual como admissíveis pela jurisprudência cinco modalidades de prisões tidas como sendo de natureza cautelar ${ }^{14}$, numa interpretação da legislação infraconstitucional obviamente não influenciada pela $\mathrm{CR}$ : a prisão em flagrante; a prisão preventiva; a prisão temporária; a prisão decorrente de sentença condenatória ou de acórdão condenatório recorrível e a prisão decorrente de pronúncia. Com as reformas de 2008, o sistema ficou reduzido a três prisões cautelares, a prisão em flagrante, a prisão preventiva e a prisão temporária.

O que ocorreu por força dessas reformas, portanto, foi que, desde então, passou-se a exigir expressamente do magistrado que demonstrasse os pressupostos para a prisão preventiva, quando foi acrescentado ao artigo 387 do Código de Processo Penal, um parágrafo único (revogado posteriormente pela Lei $n .^{\circ} 12.736 / 2012$ ), pela Lei ${ }^{\circ}{ }^{\circ} 11.719 / 08$, que impunha ao juiz que decidisse, no momento da sentença, sobre a manutenção ou recolhimento do réu, sob a modalidade de preventiva ou outra medida cautelar, de maneira fundamentada, sem prejuízo do conhecimento do recurso que viesse a ser interposto. Ocorreu com a prisão na decisão de pronúncia e na sentença condenatória proferida no Tribunal do Júri a mesma coisa, por força da Lei n. ${ }^{\circ} 11.689 / 2008$, no art. $413, \S 3$. $^{\circ}$, do CPP e no art. 492 , I, $e$, respectivamente. ${ }^{15}$

A Lei n. ${ }^{\circ} 11.719 / 08$ ainda revogou expressamente o art. 594 do Código de Processo Penal, o qual, naquele momento, já com redação alterada desde 1973, previa que, para o réu apelar, ele deveria recolher-se à prisão ou prestar fiança, exceto se fosse primário ou de bens antecedentes, circunstância que deveria ser reconhecida na sentença condenatória, ou condenado por crime de que se livrasse solto.

Mas não foi só, pois, ainda em 2008, por força das reformas ocorridas naquele ano, foram considerados tacitamente revogados por parte da doutrina brasileira os artigos 393, I, e 595, ambos do CPP, os quais dispunham, respectivamente, sobre ser efeito da sentença o recolhimento à prisão ou a sua manutenção, nos crimes inafiançáveis e nos afiançáveis, exceto se aqui prestada fiança; e sobre a deserção no recurso de apelação no caso de fuga do apelante, depois de interpô-la. Como a jurisprudência não se manifestou sobre a revogação tácita daqueles dispositivos, sobreveio, em 2011, a Lei n. ${ }^{\circ}$ 12.403, que deu por revogados expressamente os arts. 393 e 595 do CPP.

Contudo, é bom que tenhamos claro que, desde 1984, por força do art. 105 da Lei de Execução Penal, já poderiam a doutrina e a jurisprudência ter enfrentado a questão referente aos dispositivos do CPP que versavam sobre a prisão decorrente de sentença condenatória recorrível, a prisão decorrente de pronúncia, a prisão decorrente de acórdão recorrível e os que tratavam da execução provisória da pena e dos efeitos da sentença, a fim de discutir sobre a revogação tácita desses pela LEP, o que, todavia, não aconteceu. Tal deveria ter ocorrido porque, no mencionado art. 105 da LEP, fica vinculada a execução da pena ao trânsito em julgado da sentença.

$\mathrm{E}$, se a LEP não fosse argumento suficiente para revogar tacitamente os dispositivos acima mencionados, a Constituição de 1988 possibilitaria a jurisprudência refletir sobre a recepção da disciplina das prisões, dos efeitos da sentença condenatória e da execução provisória da pena pela nova ordem jurídica. Isso também não aconteceu de imediato, porém.

\footnotetext{
${ }^{14}$ Embora não seja aqui o espaço para debate acerca da natureza da prisão decorrente da sentença recorrível, cabe dizermos que a doutrina nunca foi pacífica a esse respeito, oscilando entre compreendê-la como efeito automático da condenação recorrível, como medida cautelar obrigatória, como execução provisória da pena, como regra procedimental condicionante da apelação, como prisão de natureza processual ou como prisão de natureza cautelar.

${ }^{15}$ Nesse sentido, aliás, foi a decisão da Primeira Turma da Suprema Corte ao julgar o Habeas Corpus n. ${ }^{\circ}$ 101.244MG em 16 de março de 2010.
} 
Dessa feita, embora a Constituição da República já contasse com vinte anos, e as exigências dos arts. 393, I, e 595, do CPP, não tivessem sido recepcionadas pelo texto constitucional, o que, por sua vez, não foi enfrentado pela jurisprudência, o fato é que apenas parte da doutrina reconheceu que, em 2008, houve a revogação tácita de ambos os dispositivos.

Adiante, no ano de 2011, a Lei Federal n. ${ }^{\circ} 12.403$ alterou a redação do art. 283, caput, do CPP, quando ficou disposto que ninguém poderá ser preso senão em flagrante delito ou por ordem escrita e fundamentada do juiz competente, em razão de sentença condenatória transitada em julgado ou durante investigação ou processo por meio de prisão preventiva ou temporária.

O referido art. 283 do CPP dizia, até 2011, que "A prisão poderá ser efetuada em qualquer dia e a qualquer hora, respeitadas as restrições relativas à inviolabilidade do domicílio".

Com o advento da Lei Federal n. ${ }^{\circ}$ 12.403/2011, o art. 283, caput, passou a prever que ninguém pode ser preso a não ser em flagrante ou por ordem escrita e fundamentada do juiz competente, em razão de sentença transitada em julgado, ou durante investigação ou processo, por força de prisão temporária ou de prisão preventiva.

Além disso, devemos frisar que, desde 1988, o trânsito em julgado passou a ser expressamente exigido pelo Texto Constitucional, para que o réu seja considerado culpado, segundo o art. 5. ${ }^{\circ}$, inciso LVII, da CR.

Contudo, no voto do Relator do HC n. ${ }^{0}$ 126.292/SP do STF não foi enfrentada a questão da constitucionalidade ou não do art. 283, caput, do CPP, ao passo que esse dispositivo precisaria ter sua constitucionalidade apreciada e afastada, se inconstitucional fosse, em processo concreto, porquanto o caput do art. 283 do CPP, repisemos, dispõe sobre a prisão cautelar e sobre a prisão decorrente de sentença condenatória desde que essa tenha transitado em julgado.

O que temos aqui no julgamento do HC n. ${ }^{\circ} 126.292 / \mathrm{SP}$, portanto, são problemas referentes à deficiência de fundamentação da decisão contida no voto do Ministro Relator.

Em primeiro lugar, não foi ao menos mencionado o fato de que a norma constitucional, que exige expressamente o trânsito em julgado para a superação da presunção de não culpabilidade, está acima do Pacto de São José da Costa Rica e do Pacto Internacional de Direitos Civis e Políticos, os quais, por sua vez, requerem apenas o duplo grau de jurisdição para tanto, e que a distinção de critérios para a superação da presunção de inocência adotados pela Constituição brasileira e pelos indicados Pactos Internacionais não compromete em nada a escolha primeira feita pelo Constituinte brasileiro, porque o Pacto de São José da Costa Rica não impediu os Estados de optarem por outro critério. De mesmo modo não foi observado o fato de que é possível a convivência das duas normas jurídicas sobre a presunção de não culpabilidade, tendo em conta que, no sistema brasileiro, o que se tem de fato é que o legislador foi além do sistema de superação pelo duplo grau de jurisdição, ao exigir o trânsito em julgado da sentença penal condenatória, o que evidentemente favorece o acusado.

Em segundo lugar, a legislação infraconstitucional não foi enfrentada, especialmente o art. 283, caput, do CPP, de modo que sua constitucionalidade não foi sequer discutida.

Em terceiro lugar, na interpretação do art. 5. ${ }^{\circ}$ inciso LVII, da Constituição, considerando especialmente os limites semânticos desse dispositivo que trata da presunção de não culpabilidade, o Ministro Relator, em seu voto, acabou por não tratar expressamente de possível mutação constitucional. Se o tivesse feito, obviamente deveria cuidar dos limites do fenômeno, oportunidade em que, considerando concepção demasiadamente abrangente acerca da mutação discutida naquela Corte, quando dos debates sobre o art. 52, inciso $\mathrm{X}$, da $\mathrm{CR}^{16}$, podemos dizer que não seria difícil demonstrar que a situação fática alterada poderia exigir a atualização da Constituição. Todavia, em face dos limites semânticos do princípio em comento, nesse caso mais

\footnotetext{
${ }^{16}$ Devemos deixar claro que, se a solução do problema por meio da ideia de mutação constitucional fosse encaminhada no sentido daquilo que o STF anteriormente discutiu e admitiu como mutação propriamente no caso do art. 52, inciso X, da CR, mais uma vez estar-se-ia permitindo que o fenômeno da mutação significasse, mais do que uma nova norma constitucional, um novo texto.
} 
plausível seria o STF demonstrar que gradações do princípio da presunção de não culpabilidade, que são perfeitamente admitidas no âmbito na legislação infraconstitucional e reconhecidas como constitucionais pelo próprio STF, poderiam conduzir, em regra, à antecipação da tutela penal (desde que houvesse sentença condenatória confirmada pelo segundo grau de jurisdição), sem que para tanto fosse necessária mudança no texto da Constituição, porque estaríamos diante de uma mutação constitucional.

No que tange ainda aos limites semânticos do art. $5^{\circ}$, inciso LVII, da Constituição, em seu voto o Ministro Relator também deixou de enfrentar o fato de que nesse dispositivo o constituinte vinculou expressamente, tal como diz o Ministro Barroso em seu voto, a culpabilidade - e não a prisão - ao trânsito em julgado da sentença penal condenatória.

Esse reconhecimento da ocorrência de mutação, porém, demandaria justificação minuciosa e demonstração detalhada da existência de mutação, porque é preciso lembrar que essa não pode significar rompimento com a ordem constitucional.

Em quarto lugar, se em seu voto o Ministro Relator tivesse evidenciado e realizado a ponderação como solução para o caso de tensão entre o princípio da presunção de não culpabilidade e o princípio da efetividade da função da jurisdição penal - colisão até anunciada no voto do Relator -, o que demandaria o simultâneo enfrentamento da semântica do art. 5. $^{\circ}$, inciso LVII, da CR, não bastaria fazer mera escolha de um princípio, pois ponderação não pode ser e de fato não é simples escolha.

Acontece que a fundamentação para o tratamento progressivamente mais gravoso ao acusado num sistema em que a superação da presunção de não culpabilidade ocorre, de acordo com o Texto Constitucional, com o trânsito em julgado, deu-se, pelo voto do Relator com base na demarcação do núcleo da norma jurídica que estabelece essa garantia fundamental, de sorte que para além do núcleo, que diz respeito apenas ao fato de que a produção de provas de autoria e de materialidade deve ser feita pela acusação, admite o Ministro Teori Zavascki que o legislador detém um espaço de conformação no qual poderá tratar o acusado progressivamente de forma mais gravosa. Essa demarcação restrita do núcleo, todavia, é um problema para a doutrina tradicional, que enxerga a presunção de não culpabilidade em três aspectos, dois dos quais não abordados no julgamento, pelo STF, o da garantia política, o da norma probatória e o da norma de tratamento.

Não fosse o suficiente, cabe notarmos que no julgamento do $\mathrm{HC}$ n. ${ }^{\circ}$ 126.292/SP também foram desconsiderados, a título de apreciação, os arts. 669, inciso I, e 637, segunda parte, ambos do CPP, ao passo que esses dispositivos nunca sofreram revogação expressa. Deveria o STF, assim, enfrentar o fato de que ambos poderiam estar tacitamente revogados pelo art. 105 da LEP, de 1984, ou, assim não admitindo, deveria tratar da recepção ou não pela CR de 1988. Dizem o art. 669, inciso I, e o art. 637, segunda parte, respectivamente, que a execução pode se dar mesmo que interposto o Recurso Extraordinário, e que o réu pode ser preso antes do trânsito em julgado, mesmo em caso de crime afiançável, até que seja prestada a fiança.

Demonstrados os problemas na fundamentação da decisão do voto do Ministro Relator, é importante observamos que a mudança de entendimento assinalada pelo Supremo Tribunal Federal no $\mathrm{HC}$ n. ${ }^{\circ}$ 126.292/SP acerca dos limites da norma jurídica que versa sobre a garantia fundamental da presunção de não culpabilidade tem como pano de fundo o quadro de crise vivido pelos(as) brasileiros(as), no qual se destaca o julgamento da AP 470, caso que ficou conhecido como Mensalão, quando teve início uma reação conservadora do legislador no sentido de impedir, por exemplo, que a investigação criminal fosse realizada também pelo Ministério Público, a qual foi seguida de manifestações sociais gigantescas por todo o país contrárias à corrupção. Esses movimentos sociais, que não perderam força após o julgamento do Mensalão, indicam o cansaço da sociedade brasileira com relação à corrupção e à impunidade, sentimento acirrado demasiadamente com as descobertas feitas pela Operação Lava Jato, que demonstram a institucionalização do fenômeno da corrupção no país. 
O julgamento do HC n. ${ }^{\circ}$ 126.292/SP, contudo, não está incólume de problemas relativos à fundamentação, como foi visto acima, tendo em conta que o Texto da Constituição expressamente adotou o sistema do trânsito em julgado para que a presunção de não culpabilidade seja vencida, superada, ao que devemos acrescentar que o art. 283, caput, do Código de Processo Penal, está em vigor, e que essa circunstância não foi enfrentada pela Corte Suprema brasileira.

Nas palavras do Relator do HC n. ${ }^{\circ} 126.292 / S P$, por sua vez, a presunção de não culpabilidade ou de inocência ${ }^{17}$ possui um núcleo fundamental que impõe à acusação produzir as provas de autoria e de materialidade do delito, de sorte que, para além desse núcleo, o legislador detém um espaço de conformação no qual poderá tratar o acusado progressivamente de forma mais gravosa, tendo em conta a evolução da imputação. Assim, essa evolução, segundo o voto do Relator Ministro Teori Zavascki, pode até mesmo alcançar a admissão do início da execução da pena quando ainda pendentes os recursos extraordinários, que não possuem efeito suspensivo, estando confirmada a sentença condenatória pelo segundo grau de jurisdição.

Em seu voto, o Relator, citando o Ministro Gilmar Mendes, evidencia que o ser considerado culpado de que trata o art. $5^{\circ}$, inciso LVII, da CR, não foi definido pelo constituinte, e depende da intermediação do legislador, o que, aliás, efetivamente ocorre com as medidas cautelares de natureza processual penal previstas na legislação infraconstitucional, com as exigências para recebimento da peça acusatória e também para a condenação do acusado, que não se confundem, é importante dizermos, com a antecipação de tutela, embora restrinjam até o direito de liberdade do acusado.

Contudo, essa justificação para a mudança de posicionamento do STF acerca da presunção de não culpabilidade por meio da redefinição do núcleo da norma jusfundamental demonstra fragilidade menos por deixar de compreender que não ser considerado culpado inclua, também, a norma de tratamento que diz respeito a tratar o acusado como inocente do que por não enfrentar a ideia de que a presunção de não culpabilidade tem em seu núcleo essencial a exigência de que a imposição ao réu de medidas restritivas de direitos deve ser excepcional, devendo, para isso, existir elementos probatórios justificadores da necessidade, da adequação e também da proporcionalidade em sentido estrito da medida extrema.

Deixou o Relator, também em seu voto, de enfrentar o argumento segundo o qual a Constituição de 1988 condiciona o ser considerado culpado - e não a prisão - ao trânsito em julgado da sentença penal condenatória, o que, aliás, configura um dos argumentos contidos no voto do Ministro Barroso, que, por sua vez, fala em culpabilidade, sendo que esse argumento não foi discutido por todos os membros da Corte.

Nesse sentido, poderia ter o STF enfrentado expressamente o fenômeno da mutação constitucional, relacionado que é às situações em que não ocorre uma alteração formal do Texto Constitucional, nas quais, em virtude de uma evolução na situação de fato sobre a qual incide a norma ou ainda por força de uma nova visão jurídica que passa a predominar na sociedade, a Constituição muda, sem que as suas palavras sofram modificação alguma. Dessa forma, o texto não sofre alteração, mas seu sentido muda. Entretanto, a interpretação nova deve encontrar arrimo no teor das palavras empregadas pelo constituinte e não pode ferir os princípios estruturantes Constituição, sob pena de existir somente uma interpretação inconstitucional (BRANCO; MENDES, 2015, p. 134).

Sucede que, a esta altura, há um evidente problema na ideia de mutação aplicada ao art. $5^{\circ}$, inciso LVII, da CR, porque modificar o sistema que estabelece o trânsito em julgado para a superação da presunção de inocência poderia aparentemente significar uma alteração do Texto da

\footnotetext{
${ }^{17}$ A presunção de não culpabilidade é tida como direito fundamental processual de âmbito negativo ou garantia processual. Essa classificação da doutrina brasileira de direitos e garantias fundamentais, contudo, tem seus problemas, como nos alertam Mendes e Branco (2015, p. 397), o que, por sua vez, não interessa, neste momento, ao objeto do presente trabalho.
} 
Constituição, tendo em conta os seus limites semânticos. Esse argumento em qualquer situação poderia ser fortemente contrário à mutação, se não fosse o fato de que, a uma, o trânsito em julgado ligado à superação da presunção de não culpabilidade nunca impediu gradações realizadas (e tidas como constitucionais pelo próprio $\mathrm{STF}^{18}$ ), inclusive, pela legislação infraconstitucional, para a aplicação desse princípio, especificamente no que concerne à concessão de medidas cautelares no processo penal, e, a duas, o Texto Constitucional diz que ninguém será culpado, sem dizer o que considera ser culpado.

Assim, é possível manter o sistema do trânsito em julgado, sem alteração do Texto Constitucional, conformando um novo entendimento possível do texto e admitindo que a evolução da situação de fato (todo o contexto de crise vivenciada no país) impõe que a presunção de não culpabilidade continue a ter, como de resto sempre ocorreu, gradações, mas agora para abranger o início do cumprimento da pena após a confirmação da sentença condenatória no segundo grau de jurisdição. Afinal de contas, o status libertatis de alguém condenado no primeiro grau de jurisdição que tem sentença confirmada pelo segundo grau não deve ser o mesmo de alguém que assim não se encontra. E, não fosse o bastante, em sua semântica, a Constituição sequer diz que deve ser presumido inocente até o trânsito em julgado, pois nela está prescrito que ninguém será considerado culpado até o trânsito em julgado ${ }^{19}$.

A mutação reconhecida nesses termos sequer implicaria a discordância com a presunção de não culpabilidade prevista no Pacto de São José da Costa Rica e no Pacto Internacional dos Direitos Civis e Políticos. Contudo, para haver o reconhecimento de uma mutação nos moldes citados, seria necessária uma intensa justificação por parte do STF, afinal de contas, em 2009, portanto em curto espaço de tempo, essa Corte deixou de admitir a antecipação da tutela penal.

No caso do julgamento do $\mathrm{HC} \mathrm{n} .^{\circ} 126.292 / \mathrm{SP}$, se a mutação estivesse expressamente em questão, obviamente, seus limites deveriam ser considerados na análise pelo STF, pois sabemos que, pelo menos para Hesse (1998), a mutação encontra limites que estão ligados ao próprio Texto Constitucional, sob pena de haver quebra constitucional. Assim, a nova correlação de forças que emerge em um determinado momento social, levando à identificação do fenômeno da mutação, e o próprio Texto Constitucional devem ser os limites do indicado fenômeno, significando que deve ser mantida a continuidade, não podendo, portanto, a mutação levar a uma situação de ruptura da ordem constitucional, tendo em vista que está limitada pelo sistema constitucional, nunca o podendo atingir totalmente, porque isso implicaria a revogação tácita da Constituição. Aliás, no caso da mutação constitucional, é sempre preciso considerar se a mudança social não demanda reforma da Constituição propriamente, dado que uma mutação nunca pode ser inconstitucional ${ }^{20}$.

O fato é que no julgamento do HC n. ${ }^{\circ}$ 126.292/SP a mutação constitucional realmente não foi enfrentada de modo expresso pelo STF, exceto no voto do Ministro Barroso, embora pareça a mais justificável solução para o tratamento progressivamente mais gravoso ao acusado num sistema em que a superação da presunção de não culpabilidade é possível, de acordo com o Texto Constitucional, somente com o trânsito em julgado.

A respeito do fenômeno da mutação, inclusive, tal como dissemos antes, devemos lembrar que sequer a superação da vinculatividade do Texto Constitucional parece ser um

\footnotetext{
${ }^{18}$ STF compatibilizou, por exemplo, a prisão cautelar com a Constituição da República (HC n. ${ }^{\text {o }}$ 84.078/MG), sendo que, embora a prisão cautelar e a prisão como sanção penal não se confundam, prisão cautelar não deixa de ser restrição à liberdade.

${ }^{19}$ Poder-se-ia, aqui, discutir culpa, culpabilidade e até punibilidade, à luz do Direito Penal e da Constituição.

${ }^{20}$ É bom que digamos que uma reforma constitucional para autorizar expressamente a superação da presunção de não culpabilidade pelo duplo grau de jurisdição seria muito bem-vinda e não representaria ferimento a uma cláusula pétrea, porque não significaria emenda tendente a "abolir" direitos ou garantias individuais. Aliás, a prova de que abolição nesse caso não ocorre reside no fato de que tanto o Pacto de São José da Costa Rica quanto o Pacto Internacional de Direitos Civis e Políticas adotam o sistema do duplo grau de jurisdição para superação da presunção de não culpabilidade.
} 
enorme obstáculo para a Suprema Corte brasileira, que, no passado, tratou do tema no julgamento referente à natureza do art. 52, inciso X, da $\mathrm{CR}$, embora a identificação da mutação constitucional $^{21}$ no caso da presunção de não culpabilidade nem ao menos depende da alteração do texto, realizando-se por meio da ideia de gradação da referida garantia fundamental e do que se entende por núcleo da norma que prevê a presunção de não culpabilidade.

Sobre a ideia de mutação constitucional já se manifestou o STF, quando disse que:

No poder de interpretar a Lei Fundamental, reside a prerrogativa extraordinária de (re)formulá-la, eis que a interpretação judicial acha-se compreendida entre os processos informais de mutação constitucional (...). (STF, MS 26603-DF, Rel. Min. Celso de Mello, j. 04 de outubro de 2007.)

É fato, contudo, que, em seu voto, o Relator da decisão do STF aqui tratada deixou de expressamente enfrentar o fenômeno da mutação, mesmo sendo possível vislumbrarmos tanto uma evolução na situação de fato sobre a qual incide a presunção de não culpabilidade, ligada à sensação de esgotamento da permanente sensação de impunidade relacionada, sobretudo, aos crimes de colarinho branco, por parte da maioria da sociedade brasileira, quanto o surgimento de uma nova visão jurídica que passa a predominar na sociedade no sentido de que, em regra, a sentença condenatória confirmada no segundo grau de jurisdição pode permitir a superação do princípio da presunção de não culpabilidade, sem prejuízo da obtenção de efeito suspensivo nos recursos extraordinários, a fim de evitar a impunidade gritante que ofende direitos fundamentais.

Levantadas as questões referentes à fundamentação contida no voto do Relator do HC n. ${ }^{\circ}$ 126.292/SP, devemos notar que fica evidente, de outra sorte, no próprio voto, o contexto histórico em que o Habeas Corpus está em julgamento, in verbis:

E não se pode desconhecer que a jurisprudência que assegura, em grau absoluto, o princípio da presunção da inocência - a ponto de negar executividade a qualquer condenação enquanto não esgotado definitivamente o julgamento de todos os recursos, ordinários e extraordinários - tem permitido e incentivado, em boa medida, a indevida e sucessiva interposição de recursos da mais variada espécie, com indisfarçados propósitos protelatórios visando, não raro, à configuração da prescrição da pretensão punitiva ou executória.

Tem-se, dessa sorte, que a simples leitura do voto do Relator deixa clarividente a preocupação com a eficácia da prestação jurisdicional que padece em face dos sucessivos recursos e, sabemos nós, do advento da prescrição penal nesse período em que os recursos tramitam. Por isso o Ministro Teori Zavascki diz, tal como antes mencionado, que é preciso, além de refletir sobre o alcance da presunção de não culpabilidade, buscar o equilíbrio entre esse princípio e a efetividade da função da jurisdição penal, oportunidade em que, sem desprezar os valores ligados ao acusado, afirma ser necessário preservar igualmente os valores que protegem a sociedade, em razão de nosso sistema de justiça criminal.

Ainda em relação à decisão proferida no HC n. ${ }^{0}$ 126.292/SP, impende compreendermos que o indicativo de mudança na jurisprudência do STF acerca da presunção de não culpabilidade não pode sofrer com críticas pautadas especificamente na mudança de entendimento que fere a vontade do legislador constituinte originário até então respeitada, porquanto, como vimos antes, com o advento da CR de 1988 a jurisprudência entendia que a prisão poderia ter seu cumprimento iniciado antes do trânsito em julgado, sendo que foi a partir do HC n. ${ }^{\circ}$ 84.078/MG que houve mudança jurisprudencial consistente, fazendo com que fosse adotado o sistema

\footnotetext{
${ }^{21}$ Aqui é pertinente lembrarmos que a jurisprudência não realiza mutação, ela apenas reconhece o acontecimento
} dessa, que é espontâneo.

Revista de Direito Brasileira | São Paulo, SP | v. 16 | n. 7 | p. 21 - 42 | Jan./Abr. 2017 
segundo o qual a superação da presunção de inocência dependeria do trânsito em julgado da sentença condenatória.

Estamos, portanto, em 2016, diante de uma possibilidade de nova mudança na jurisprudência do STF, mudança essa que está claramente relacionada com a crise política pela qual passa a sociedade brasileira.

Nessa linha, o que podemos entrever é a existência de uma inconformidade advinda das ruas, aliada ao inconformismo dos que operam o direito combatendo a criminalidade de colarinho branco especialmente, em relação à impunidade e à corrupção, que pode compor o quadro da crise vivida no Brasil ${ }^{22}$. É possível vislumbrarmos que em momentos de crise como o presente possam ocorrer confrontos em distintas dimensões, inclusive na atividade legislativa e na jurisprudência, entre o interesse público e a segurança jurídica, o que sempre pode trazer alguns riscos. Aliás, crises podem trazer, além de perigos, oportunidades e também rupturas.

Nesses momentos direitos e garantias fundamentais correm riscos de ser tangenciados, tal como se pode observar no indicativo de mudança de entendimento do STF acerca do princípio da presunção de não culpabilidade, o que efetivamente sempre pode ser um sério problema.

Em momentos de grave crise, como a atual vivenciada no Brasil, que assume contornos econômicos, políticos e, especialmente éticos, pois está no mínimo em jogo nosso histórico desprezo pela ideia bem de $\operatorname{todos}^{23}$, a jurisprudência e também a atividade legiferante tendem a se manifestar, buscando ora soluções boas ora soluções muito ruins para a crise, as quais podem tangenciar direitos e garantias fundamentais, que, mesmo não sendo absolutos ${ }^{24}$, devem, no mínimo, ser preservados em seu núcleo essencial, sob pena de retrocesso odioso.

No caso do HC n. ${ }^{\circ}$ 126.292/SP, em que pese todas as questões acima levantadas sobre os problemas na fundamentação, fica sinalizado, portanto, que está em curso uma possível mudança na jurisprudência do STF acerca do princípio da presunção de não culpabilidade, a qual guarda relação com a grave crise pela qual passa o Brasil, até mesmo porque isso pode ser extraído da literalidade do voto do Ministro Relator do Habeas Corpus. Contudo, somente os julgados posteriores poderão nos dizer se houve efetivamente uma mudança na jurisprudência do STF sobre o princípio da presunção de não culpabilidade e a antecipação da tutela penal.

\section{CONCLUSÃO}

Na história institucional brasileira as crises políticas e econômicas não são novidades. Atualmente, contudo, a crise brasileira tem muitas peculiaridades, pois o país passa por um processo que teve início com o julgamento do caso do Mensalão e que ganhou ainda maior importância com a Operação Lava Jato de combate à corrupção.

Sem que o estado e as instituições estejam em perigo, a presente crise põe em risco a economia e as políticas públicas que objetivam efetivar direitos fundamentais, quando constatamos que recursos públicos e o patrimônio de empresas públicas passaram a ser desviados de modo institucionalizado para campanhas políticas e particulares, por meio de empresas que colaboravam com essas campanhas em troca de vitórias em licitações fraudulentas.

Ocorre que a crise, que teve início relacionado com os escândalos de corrupção investigados e punidos legal e constitucionalmente, repercutiu nas ruas, nas poderosas redes

\footnotetext{
${ }^{22}$ Basta vermos as propostas do MPF de combate à corrupção, que já resultaram na coleta de mais de dois milhões de assinaturas em todo o país destinadas à elaboração de lei por iniciativa popular. Disponível em < http://www.combateacorrupcao.mpf.mp.br/10-medidas>. Acesso em: 23 de março de 2016.

${ }^{23}$ A ideia em Aristóteles (2009) de que a ética na esfera individual geraria a estrutura para a política, que teria como objetivo alcançar o bem de todos está longe do que, no Brasil, a crise atual demonstra.

${ }^{24}$ Convém observarmos, nesse caminho, que tratados internacionais sobre direitos humanos assim como a CR de 1988 trazem hipótese expressas de situações em que direitos ou garantias fundamentais cedem em face de outros, exemplo disso é o direito à vida, em caso de guerra declarada, quando se admite a pena de morte.
}

Revista de Direito Brasileira | São Paulo, SP | v. 16 | n. 7 | p. 21 - 42 | Jan./Abr. 2017 
sociais e na opinião pública de um modo geral, produzindo um sentimento que perpassa a sociedade de inadmissão da corrupção e da impunidade.

Obviamente que as crises tendem a causar impacto, dentre outras áreas, na atividade legiferante e na jurisprudência, que não estão imunes a elas. E, nesses dois casos, o que de mais preocupante pode acontecer é que direitos fundamentais sejam tangenciados pelas crises.

No caso aqui visto, a partir da análise do recente julgamento realizado pelo STF do HC n. ${ }^{\circ}$ 126.292/SP, podemos constatar que é claro o fato de que a garantia fundamental da presunção de não culpabilidade foi tangenciada, tendo o núcleo da norma sido redefinido, ainda que sem o necessário enfrentamento de algumas importantes questões relacionadas às normas previstas na legislação infraconstitucional e aos desafios que a literalidade do Texto Constitucional impõe ao dispor sobre o princípio em comento, estando a decisão centrada redefinição do núcleo da norma fundamental.

A respeito da presunção de não culpabilidade, é merecido lembrarmos, contudo, que, como qualquer garantia constitucional essa não é absoluta, como aliás não o são os direitos fundamentais, tanto que direitos e garantias fundamentais ou valores com sede constitucional podem e às vezes até devem limitar outros direitos e garantias fundamentais ou outros valores, em determinadas situações. Aliás, na legislação infraconstitucional o próprio princípio da presunção de não culpabilidade já sofre gradações que afastam sua absolutividade, o que podemos depreender, por exemplo, dos motivos legais para a decretação da prisão preventiva, que é instituto perfeitamente compatível com os ditames constitucionais, nos termos do que, inclusive, já foi decidido pelo STF, em 2009. Assim, da garantia da ordem pública e da ordem econômica, passando pela conveniência da instrução criminal até chegarmos à necessidade de assegurar a aplicação da lei penal, a ofensa ao princípio da presunção de não culpabilidade sofre uma diminuição gradativa (MOSSIN, 2005, p. 625).

Esse mesmo fenômeno da gradatividade da presunção de não culpabilidade em nível infraconstitucional pode ser percebido, também, em relação às demais medidas cautelares dispostas no Código de Processo Penal, que são igualmente compatíveis com a Constituição de 1988, e também no recebimento da peça acusatória pelo magistrado.

A isso soma-se o fato e que a inalienabilidade/indisponibilidade, a universalidade e absolutividade, enquanto características dos direitos fundamentais, devem ser compreendidas em termos, de sorte que, como consequência, esses adjetivos não devem impedir restrições de direitos e de garantias fundamentais em prol de uma finalidade acolhida ou tolerada pela ordem constitucional, o que, aliás, algumas vezes tem previsão normativa (BRANCO; MENDES, 2010, pp.3142-146).

Em verdade, a decisão proferida pelo STF no HC n. ${ }^{\circ}$ 126.292/SP está evidentemente inserida no contexto histórico em que foi produzida, ao mesmo tempo em que o evidencia. $\mathrm{E}$ nesse contexto são claras as mazelas decorrentes da compreensão da presunção de não culpabilidade como princípio que, para ser superado, necessita do transito em julgado até para a prisão do acusado condenado em primeiro e segundo grau de jurisdição e de um não aprofundamento da reflexão sobre a própria literalidade do Texto Constitucional. Nesse segundo caso, aliás, seria pertinente partir da constatação de que no art. $5^{\circ}$, inciso LVII, está dito, primeiramente, que ninguém será culpado até o trânsito em julgado, o que implica dizer que o constituinte trata de culpa propriamente, sem dizer o que seja, e ainda condiciona a culpa - e não a prisão - ao trânsito em julgado da sentença penal condenatória.

Essa concepção do princípio da presunção de não culpabilidade e um sistema recursal absolutamente desmedido e com infindáveis recursos fomentam, no Brasil, a corrupção e a impunidade, e, mais grave do que isso, geram um sistema de justiça absolutamente assimétrico, que livra os que possuem dinheiro ou poder e condena os pobres e/ou sem instrução. 


\section{REFERÊNCIAS}

ALEXANDRINO, José de Melo. Jurisprudência da crise. Das questões prévias às perplexidades. In: RIBEIRO, Gonçalo de Almeida; COUTINHO, Luís Pereira (org.). O Tribunal Constitucional e a Crise. Ensaios críticos. Coimbra: Almedina, 2014, pp. 57 - 61.

ARANTES FILHO, Marcio Geraldo. Notas sobre a tutela jurisdicional da presunção de inocência e sua repercussão na conformação das normas processuais penais à constituição brasileira. In: Revista Liberdades, n. ${ }^{\circ}$ 4, maio-agosto, 2010, pp. 24-43. Disponível em < file:///C:/Users/Marques/Downloads/Revista-n-4-Maio-Agosto-de-2010.pdf>. Acesso em: 02 de abril de 2016.

ARISTÓTELES. Ética a Nicômaco. Trad. Antônio de Castro Caeiro, São Paulo: Editora Atlas, 2009.

BRANCO, Paulo Gustavo Gonet; MENDES, Gilmar Ferreira. Curso de Direito Constitucional. $10^{a}$ ed., revista e atualizada, São Paulo: Saraiva. 2015.

BUENO, Cássio Scarpinella. Novo Código de Processo Civil Anotado. São Paulo: Saraiva, 2015.

HESSE, Konrad. Elementos de Direito Constitucional da República Federal da Alemanha. Porto Alegre: Sérgio Antônio Fabris, 1998.

HOLANDA, Sérgio Buarque. Raízes do Brasil. 27a , São Paulo: Companhia das Letras, 2014.

HOUAISS, Antônio. Dicionário eletrônico Houaiss da língua portuguesa. Rio de Janeiro: Objetiva. Versão 1.0. 1 [CD-ROM]. 2001.

GOMES, Luís Flávio. Sobre o conteúdo processual tridimensional da presunção de inocência. In: GOMES, Luiz Flávio. Estudos de Direito Penal e Processual Penal. São Paulo: Editora Revista dos Tribunais, 1998.

LAMOUNIER, Bolívar. Vivemos cinco anos de uma gestão criminosa. São Paulo: Revista Istoé. 11 de maio de 2016, ano 39, n. ${ }^{\circ}$ 2422. Entrevista concedida a Mariana Queiroz Barboza.

MOSSIN, Heráclito Antônio. Comentários ao Código de Processo Penal: à luz da doutrina e da jurisprudência. Barueri: Manole, 2005.

OFFE, Claus. Capitalismo desorganizado: transformações contemporâneas do trabalho e da política. São Paulo: Brasiliense, 1995.

PINHEIRO, Alexandre Souza. A jurisprudência da crise: Tribunal Constitucional português (2011-2013). In: Observatório da Jurisdição Constitucional. Ano 7, N. 1, jan/jun. 2014.

PINTO, Paulo Mota. A proteção da confiança na "jurisprudência da crise". In: RIBEIRO, Gonçalo de Almeida; COUTINHO, Luís Pereira (org.). O Tribunal Constitucional e a Crise. Ensaios Críticos. Coimbra: Almedina, 2014, pp. 135- 181.

SAMPAIO, José Adércio Leite. Constituição e Crise Política. Belo Horizonte: Del Rey, 2006. 
SÁNCHEZ, Jésus Maria Silva. A expansão do direito penal: Aspectos da política criminal nas sociedades pós-industriais. São Paulo. Revista dos Tribunais, série As Ciências Criminais no Século XXI - v. 11, Trad. Luiz Otavio de Oliveira Rocha, 2002.

SARAH, Marta Ferreira Santos. Política e sociedade: as manifestações de rua de 2013 a $2015 . O$ Estadão. São Paulo, 12 de maio 2015. Disponível em < http://politica.estadao.com.br/blogs/gestao-politica-e-sociedade/politica-e-sociedade-asmanifestacoes-de-rua-de-2013-e-2015/>. Acesso em: 02 de março de 2016.

SILVA, José Afonso da. Mutações Constitucionais. In: Poder Constituinte e Poder Popular (estudos sobre a constituição). São Paulo: Malheiros. 2007.

TORRES, Jaime Vegas. Presunción de inocência y prueba en el processo penal. Madri: La Ley, 1993.

UNGER, Mangabeira. Os partidos políticos brasileiros estão viciados na ideia de Suécia tropical. São Paulo: 2014. Época, 08 nov. 2014. Entrevista concedida a Pedro Marcondes de Moura. Disponível em < http://centraldeatendimento.blogspot.com.br/2012/11/revista-epoca-sac.html > Acesso em: 20 de março de 2016.

URBANO, Maria Benedita. A jurisprudência da crise no divã: diagnóstico: bipolaridade? In: RIBEIRO, Gonçalo de Almeida; COUTINHO, Luís Pereira (org.). O Tribunal Constitucional e a Crise. Ensaios Críticos. Coimbra: Almedina, 2014, pp. 11-48. 